\title{
Description of the last nymphal instar of Talipes appendiculatus (Hemiptera: Membracidae: Membracinae), and notes on the biology of the immatures and adults
}

\author{
Frederico Lencioni-Neto ${ }^{1}$ \& Albino M. Sakakibara ${ }^{2}$
}

\begin{abstract}
'Museu de História Natural de Taubaté. Rua Juvenal Dias de Carvalho 111, Jardim do Sol, 12070-640 Taubaté, SP, Brazil. E-mail: Iencioni@univap.br ${ }^{2}$ Departamento de Zoologia, Universidade Federal do Paraná. Caixa Postal 19020, 81531-980 Curitiba, PR, Brazil. E-mail: amsakakibara@pq.cnpq.br
\end{abstract}

\begin{abstract}
The last instar nymph of Talipes appendiculatus (Fonseca) is described and illustrated, and biological data are given on the immatures and adults. The $5^{\text {th }}$ instar nymph has the body covered with tuberculate chalazae; head and thorax without scoli; abdomen with terga III-VIII with single dorsal scoli, all different in size, III and VIII small, V the largest about $2 x$ longer than wide. Descriptions of the adults (male and female) are also provided, with the addition of some new characters. The species (adults, immatures of various stages) has been collected on branches of Cassia fistula L. (Leguminosae: Caesalpinioidea), and is frequently attended by bees and wasps.
\end{abstract}

KEYWORDS. Description, nymphal stages, Talipedini, taxonomy, treehopper.

Talipes was described by Deitz (1975) based on Tylopelta appendiculata Fonseca, 1936, a species originally included in Membracini. Since the species differs from other Membracini in some characteristics (forewing venation simple, not reticulate, metathoracic tibiae not foliaceous, clavate distally, metatarsus much shorter than pro- and mesothoracic tarsi), the author transferred Talipes to a new tribe, Talipedini. Years later, McKAMEY \& Deirz (1991) discovered that Trinarea Goding, 1926 (type species: Ochropepla carinata Funkhouser, 1922), formerly described as a subgenus of Hoplophorion Kirkaldy, shared a large number of characters with Talipes. Based on that, they considered the latter as a junior synonym of Trinarea. With this synonym, two additional species were included in the tribe Talipedini Deitz (joining Trinarea appendiculata (Fonseca)): T. carinata (Funkhouser), and T. fenestrata (Strümpel, 1974). SAKAKIBARA (2012) redefined Talipedini, reinstated Talipes and added two other genera to it, Erechtia Walker, 1858 (= Trinarea Goding) and Pseuderechtia Sakakibara, 2012. Talipes remained with two species, Talipes appendiculatus (Fonseca) and $T$. fenestratus (Strümpel). In the present paper, immatures of $T$. appendiculatus are described for the first time and biological data are also provided about the species.

\section{MATERIAL AND METHODS}

The specimens of T. appendiculatus were observed and collected (January, 2016) at an urban area of Santa Branca city, state of São Paulo (232 $23^{\prime} 59^{\prime \prime}$ S, $\left.45^{\circ} 53^{\prime} 12^{\prime \prime} \mathrm{W}\right)$, a place with many trees and lots of shade. Nymphs at different stages of development were found on the lower branches of Cassia fistula L. (Leguminosae, Caesalpinioidea), an exotic plant introduced from India, and which is widely disseminated throughout Brazil as an ornamental plant. Some immatures were brought to the laboratory and maintained for observation. The emergence of an adult female was observed through the whole process of ecdysis. The immatures (also egg mass) and adults were photographed either in nature or in the laboratory using a Canon Power Shot Sx1015, with macro and super-macro lens, and also with Dino Capture connected to a Hund Wezlar stereomicroscope, to capture fine details. The presence of wasps, bees, and ants feeding on the honeydew produced by the nymphs of T. appendiculatus was also recorded.

The terminology used for the description of immatures follows McKamey et al. (2015). Vouchers of adults and immatures are deposited in Coleção de Entomologia Pe. J.S. Moure, Departamento de Zoologia-UFPR, Curitiba (DZUP). 


\section{TAXONOMY}

\section{Talipes appendiculatus (Fonseca, 1936)}

Tylopelta appendiculata Fonseca, 1936: 158 (type locality: BRAzIL, Pernambuco, Tapera); Strümpel, 1974: 539.

Talipes appendiculata [sic]; Deitz, 1975: 41.

Trinarea appendiculata; McKamey \& Deitz, 1991: 195; McKamey, 1998: 215 (cat.).

Talipes appendiculatus; Sakakibara, 2012: 573.

Description of adult (SAKAKIBARA 2012, in part). Female (Figs. 1, 2). Color yellowish-brown, blackish on head and metopidium, and on top of median carina; forewings castaneous, opaque, with an oblique band formed by white and blackish dots crossing the membrane from costal margin to apex of clavus, apex and limbus clear translucid; legs light castaneous.

Head (Fig. 2) wider than long between eyes; eyes globose; ocelli located above transocular line, almost equidistant to each other and to eyes, closer to superior margin of head; postclypeus flat, triangular, axe-shaped, slightly convex at middle, much wider than long, widely rounded at apex, with tuft of long hairs at apex.

Pronotum (Fig. 1), in lateral view, with pre- and post-metopidium well marked; top of post-metopidium projected forwards forming a small rounded process, strongly compressed at base, thickened in front and foliaceous posterodorsally; dorsal contour line bisinuate, distinctly humped at middle; median carina percurrent; primary lateral carinae strong, laminar, much elevated above humeral angles, slightly higher than median carina, extended posteriorly to middle of lateral margin; latero-apical carinae conspicuous; secondary lateral carinae (1-2) very weak, wrinkle-like; suprahumeral carinae short, conspicuous.

Forewings coriaceous on costal margin and basal half of clavus; membrane opaque, micro-reticulate, clear translucent at apex; limbus wide and wrinkled; veins conspicuous, with simple line of hairs at each side; three discoidal cells (one $s$, two $m-c u$ and two $r-m$ crossveins), internal discoidal cell about $2 \mathrm{x}$ smaller than external.

Legs with prothoracic tibiae spatulate, mesothoracic tibiae foliaceous; metathoracic tibiae club-like, curved inwards, dilated at apex, with tarsi very reduced.

Abdomen with sternum III with mid-ventral tubercle, sternum IV with transverse keel; sternum VII widely and deeply emarginated at posterior margin; pygofer large, about as long as all preceding abdominal segments together, visibly flattened ventrally; apex of valvulae slightly exceeding pygofer.

Male (Figs. 3-7). Similar to the female, smaller, with anterior projection of pronotum reduced, only angulate at the top of post-metopidium (Fig. 3), general color much darker, with disc of head, median carina and lateral carinae above humeral angles, underside of thorax, black. Forewings dark castaneous; internal discoidal cell small (about 2x smaller than external cell). Pygofer small, hairy, lateral plate well developed, detached from pygofer, hairy at apex (Fig. 4); subgenital plate scoop-shaped, apically notched (Figs. 5, 6); aedeagus slender, cylindrical, strongly curved upwards, tapering to apex, with minute teeth on dorsal surface (Figs. 5, 6); styles curved distally, hook-like, apex pointed (Fig. 7).

Measurements (mm). Female/male. Total length 4.80/4.20; length of pronotum 4.00/3.20; width of head 2.08/1.90; length of head 1.00/1.10; width between humeral angles 2.40/2.20.

Material examined. 10 females and 6 males, labeled "BRASIL. São Paulo | Santa Branca - 15/I/2016 | F. Lencioni Neto col."; "Talipes | appendiculatus | (Fonseca, 1936)". All deposited in DZUP.

Distribution. Panama, Colombia, Peru, and Brazil (PE, MT, GO, MG, RJ, SP, PR, SC).

Remarks. Talipes appendiculatus is widely distributed, occurring from Panama to southern Brazil. This species was described by Fonseca (1936) based on a female specimen (from Pernambuco). This specimen has the pronotum projected forward into a short process. This process, however, is not present in all specimens examined. In fact, many specimens lack it, while females from Rio de Janeiro and São Paulo (Vale do Paraiba) have a projected horn. The males, on the other hand, exhibit, in some cases, only a slightly angulate tubercle on the top of the metopidium.

Last instar nymph (Figs. 8-10). Description. Overall body. Total length $3.50 \mathrm{~mm}$. Covered with tuberculate chalazae, chalazal setae simple, needlelike; dorsal contour of abdomen in lateral view (not including segment IX) subtriangular, the highest point at segment V. Head. Covered with chalazae; triangular, about $3 \mathrm{x}$ wider than long, deep furrow along coronal suture, vestigial ocelli distinct, superior margin of vertex arched, extended above tangential line of eyes; scoli absent. Prothorax. Pre-and postmetopidum distinct, the latter strongly depressed at base of posterior extension, without scoli; posterior extension of pronotum reaching posterior margin of metanotum. Mesothorax. Scoli absent; forewing pad with costal margin straight, with sparse chalazae more or less disposed along the veins. Metathorax. Similar to the former, without scoli. Legs. Chalazae of tibia very small, on lateral margins and many on dorsal surface; pro- and mesothoracic tarsi subequal in size, metathoracic tarsi shorter. Abdomen. Terga III-VIII with single dorsal scoli, all different in size, III and VIII small, $\mathrm{V}$ the largest, about $2 \mathrm{x}$ longer than wide. Chalazae distributed along marginal area. Segment IX. Dorsal length subequal to combined length of segments IV-VIII; apex with chalazae; ventral extension subequal to dorsal extension.

Material examined. 12 last instar nymphs, labeled "BRASIL. São Paulo | Santa Branca - 15/I/2016 | F. Lencioni Neto col."; "Talipes | appendiculatus | (Fonseca, 1936)". All deposited in DZUP.

Remarks. The immatures (Fig. 11) of different stages are quite similar to one another except in body size and the degree of pronotal and wing pad development. The general color also remains unchanged throughout development, yellowish-brown or brown. The $1^{\text {st }}$ instar is about $0.90 \mathrm{~mm}$ long, covered with chalazae, without either pronotal extension or wing pads; ab- 

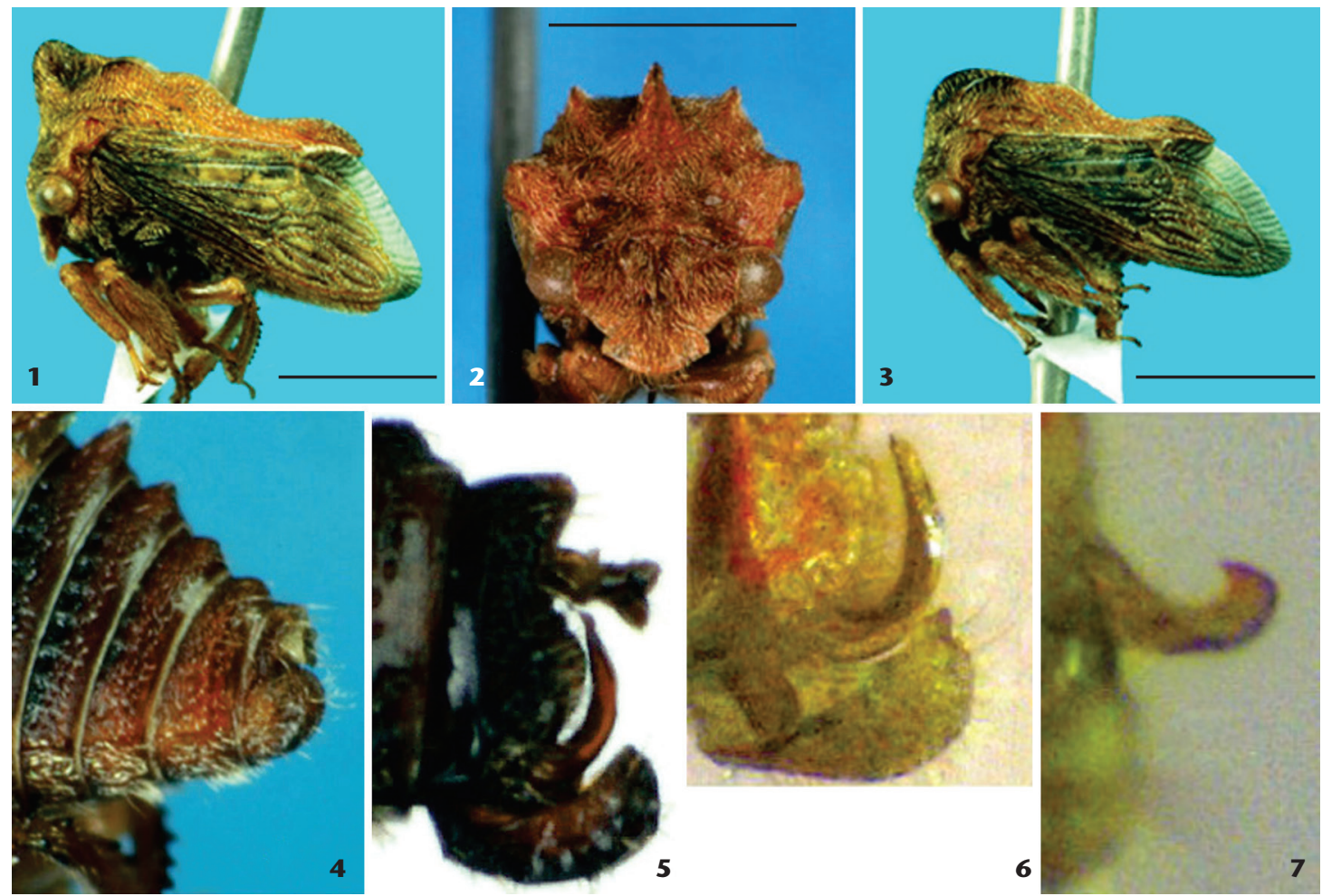

Figures 1-7. Talipes appendiculatus. Female: 1-2, lateral and frontal view. Male: 3, lateral view; 4, apex of abdomen. Genitalia: 5-6, pygofer, subgenital plate and aedeagus; 7 , style. Scale bars: $2.0 \mathrm{~mm}$.

dominal terga scoli small, paired. The $2^{\text {nd }}$ instar is about 1.80 mm long, already with a short pronotal extension as well as wing pads; abdominal scoli well developed, paired. The $3^{\text {rd }}$ instar is about $2.15 \mathrm{~mm}$ long; pronotal extension not surpassing posterior margin of mesonotum. The $4^{\text {th }}$ instar is about $2.80 \mathrm{~mm}$ long, quite similar to the $5^{\text {th }}$ instar, pronotal extension almost reaching posterior margin of metanotum. In this stage, the abdominal scoli are not paired, but are fused into a single median scolus, sometimes just bilobed apically.

Terga I-II, in the $5^{\text {th }}$ instar nymph, are normally hidden by the posterior portion of the metathorax. They can be visualized after forcing the abdomen down (fresh specimens); their texture (smooth and without chalazae) differs from the texture in the rest of the abdomen (Figs. 9, 10). Tergum I has a pair of slender, fingerlike projections submedially, white in color, directed upand backwards (scoli ?) (Fig. 10, and also in some specimens in Fig. 11). Tergum II lacks differentiated structures.

Adult emergence (Fig. 11a). The dorsal integument of the $5^{\text {th }}$ instar nymph first splits near the base of the abdomen. Subsequently, the splitting extends over the entire thorax, thus liberating the head, the thorax (with the projection of the pronotum already visible) and the abdomen, through a slow, in an out, up and down movement of the body. The anal tube, in this last moment, is extruded and elongated in the effort to push the body completely out of the exuviae. The entire process of ecdysis takes approximately 50 minutes. The emerged imago has a light-green body, with greenish-yellow legs, and orange on the ventral side of the forewings. The imago, as soon as it leaves the exuviae, stays on a branch with the head positioned upwards, and the expansion of the fore- and hind wings occurs slowly. The entire process takes approximately 70 minutes, during which the insect moves the body to different positions several times.

Behavior. The eggs are laid in the tissue of the host plant (Fig. 14), always at the end of a flowered branch (Fig. 15 - Cassia fistula L. (Leguminosae, Caesalpinioidea)). The nymphs and adults concentrate on branches that have flowers, more frequently at the lower branches in shady places. The female remains on the egg-mass protecting it (Fig. 14). The immatures of different stages are seen together with adult females and males (more males), and are attended by ants, bees, and wasps (Figs. 12,13) collecting honeydew. The bees were identified as Oxytrigona tataira (Smith) (Apidae-Meliponini) (Fig. 13), popularly known as "abelha cospe-fogo" (fire-spitter bee) due to the formic acid present in their saliva. Wasps (Fig. 12 - Vespidae) were also observed touching the nymphs with their antennae, which elicited the liberation of exudates. One species of ant (unidentified) was observed in association with the treehoppers. 

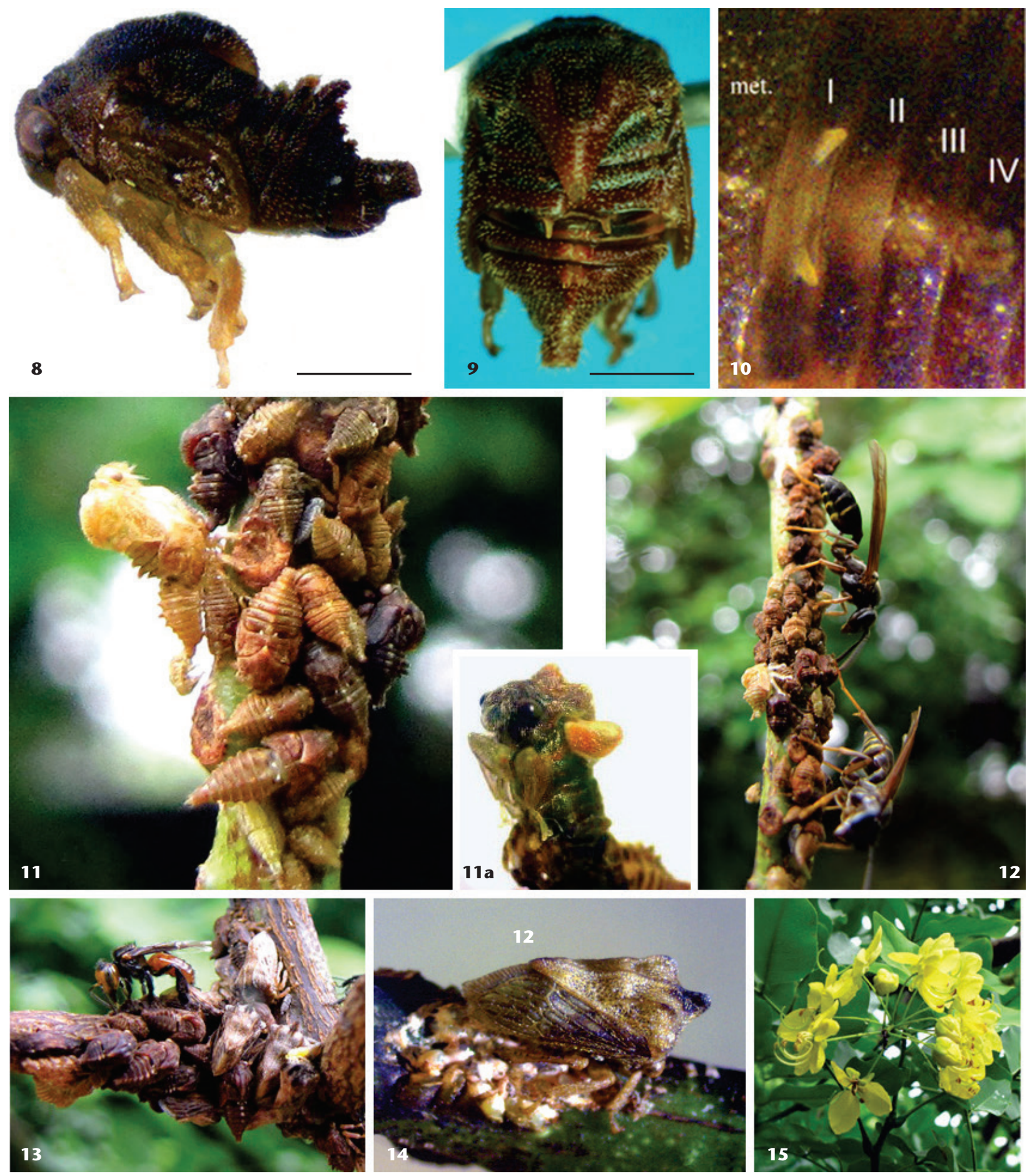

Figures 8-15. Talipes appendiculatus, associated insects and host plant. Nymphs: 8-9, $5^{\text {th }}$ instar in lateral and dorsal view; 10 , details of the abdominal terga I-IV, showing the finger-like projections on tergum I; 11, nymphs in different stages, one of them in process of ecdysis; 11a, emergence of an adult (female). Hymenoptera: 12-13, bee Oxytrigona tataira (Smith) (Apidae-Meliponini) and wasps (Vespidae) collecting honey dew. Posture: 14, female on the egg mass. Host plant: 15, flowered branch of Cassia fistula L. (Leguminosae, Caesalpinioidea). Scale bars: $1.0 \mathrm{~mm}$. 


\section{ACKNOWLEDGMENTS}

We would like to thank Dr. Vera Imperatriz Fonseca for the identification of the bee; also to Clélia Aparecida Lencioni de Souza for granting permission to collect and observe the membracids in her property.

\section{LITERATURE CITED}

Deitz LL (1975) Classification of the higher categories of the New World treehoppers (Homoptera: Membracidae). North Carolina Agricultural Experiment Station, Technical Bulletin 225: 1-177.

FonsECA JP DA (1936) Contribuição para o conhecimento dos membracídeos Neotrópicos. Archivos do Instituto Biológico 7: $157-166$.

McKamey SH (1998) Taxonomic catalogue of the Membracoidea (exclusive of leafhoppers): second supplement to fascicle I - Membracidae of the General Catalogue of the Hemiptera. Memoirs of the American Entomological Institute 60: 1-377.

McKamey SH, Deitz LL (1991) Nomenclatural changes in the treehopper tribes Hoplophorionini, Smiliini, and Talipedini (Homoptera: Membracidae). Proceedings of the Entomological Society of Washington 93: 193-196.
McKamey SH, Wallner AM, Porter MJ (2015) Immatures of the New World treehopper tribe Amastrini (Hemiptera, Membracidae, Smiliinae) with a key to genera. ZooKeys 524: 65-87. doi: 10.3897/zookeys.524.5951

SAKAKIBARA AM (2012) Taxonomic reassessment of the treehopper tribe Talipedini with nomenclatural changes and descriptions of new taxa (Hemiptera: Membracidae: Membracinae). Zoologia 29: 563-576. doi: 10.1590/s1984.46702012000600008 STRÜMPEL H (1974) Beitrag zur Kenntnis der neotropischen Membraciden Gattung Tylopelta Fowler, 1894. Entomologische Mitteilungen aus dem Zoologischen Museum Hamburg 4: 531-540.

Submitted: 14 June 2016

Received in revised form: 16 August 2016

Accepted: 24 August 2016

Editorial responsibility: Gabriel L.F. Mejdalani

Author contributions: FL-N biology and field observation; AMS taxonomy.

Competing Interests: The authors have declared that no competing interests exist. 